\title{
Book Review: Kropotkin and the Anarchist Intellectual Tradition by Jim Mac Laughlin
}

[LSE

blogs.Ise.ac.uk/lsereviewofbooks/2016/09/28/book-review-kropotkin-and-the-anarchist-intellectual-tradition-by-jim-maclaughlin/

$9 / 28 / 2016$

In Kropotkin and the Anarchist Intellectual Tradition, Jim Mac Laughlin revisits the work of influential anarchist philosopher Peter Kropotkin, tracing both his life and the broader historical development of anarchist thought. Particularly praising the book's discussion of 'scientific anarchism' and its relevance for an anarchist political geography, Taylor R. Genovese welcomes this study as an excellent contribution to the current 'anarchist Renaissance' and recommends it to those looking to be inspired to revolutionary praxis.

If you are interested in this book review, you may also like to check out the programme of 'Resist: Festival of Ideas and Actions', a three-day event being held by LSE Sociology between 28-30 September 2016 that aims to draw students and the wider public into the ways resistance has been interpreted and understood within academia, the arts, activism, student debate and mainstream politics.

Kropotkin and the Anarchist Intellectual Tradition. Jim Mac Laughlin. Pluto Press. 2016.

Find this book: amazon

In the past fifteen years, the academy as a whole - and particularly those in the social sciences - have begun to rediscover and interface with anarchist thought and what Jim Mac Laughlin has dubbed the 'anarchist intellectual tradition'. Yet to the public at large, anarchy and anarchists are largely associated with either riotous violence, political assassinations and disregard for 'law and order' or seen as naïve believers in an utopian creed. Mac Laughlin's book hopes to dispel these inaccuracies through the historical and theoretical lens of one of anarchism's most influential theorists: Pyotr Alexeyevich Kropotkin.

Since the end of the twentieth century, there has been a blossoming revitalisation of anarchist thought. With the advent of the alter-globalisation and Occupy movements, as well as global, decentralised protest groups like Black Lives Matter and Nuit Debout, there seems to be a renewed interest in engaging with anarchist principles, such as consensus decision-making, mutual aid and the rejection of state authority and oppression. Kropotkin was influential in the development of anarcho-communism and 'scientific anarchism'. At a time when Charles Darwin's

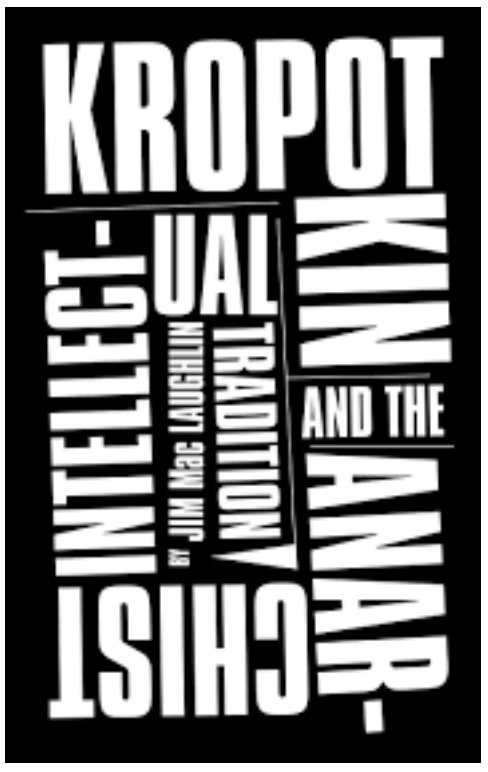
theories of evolution were beginning to be adapted to explain the ways societies developed, leading to racist ideas of societal 'progression' and the inaccurate dichotomy of 'savage' vs 'civilised' peoples, Kropotkin argued that mutual aid, as opposed to competition, drove social evolution.

In the first half of the book, Mac Laughlin takes an in-depth look into Kropotkin's life and the historical lineage of anarchistic thought. He begins his journey in ancient Greece, where the word 'anarchy' was conceived by combining the prefix 'an' ( $\square v-$ in absence of) and 'archos' ( $\square \rho x o ́ s-$ ruler or authority) (1). This term was originally utilised to describe those that lived outside of military or city-state control. Mac Laughlin then gives a thorough discussion of anarchic thought in ancient Greek philosophy as well as a historical overview of figures such as Gerrard Winstanley and the Digger movement, William Godwin and Pierre-Joseph Proudhon. 


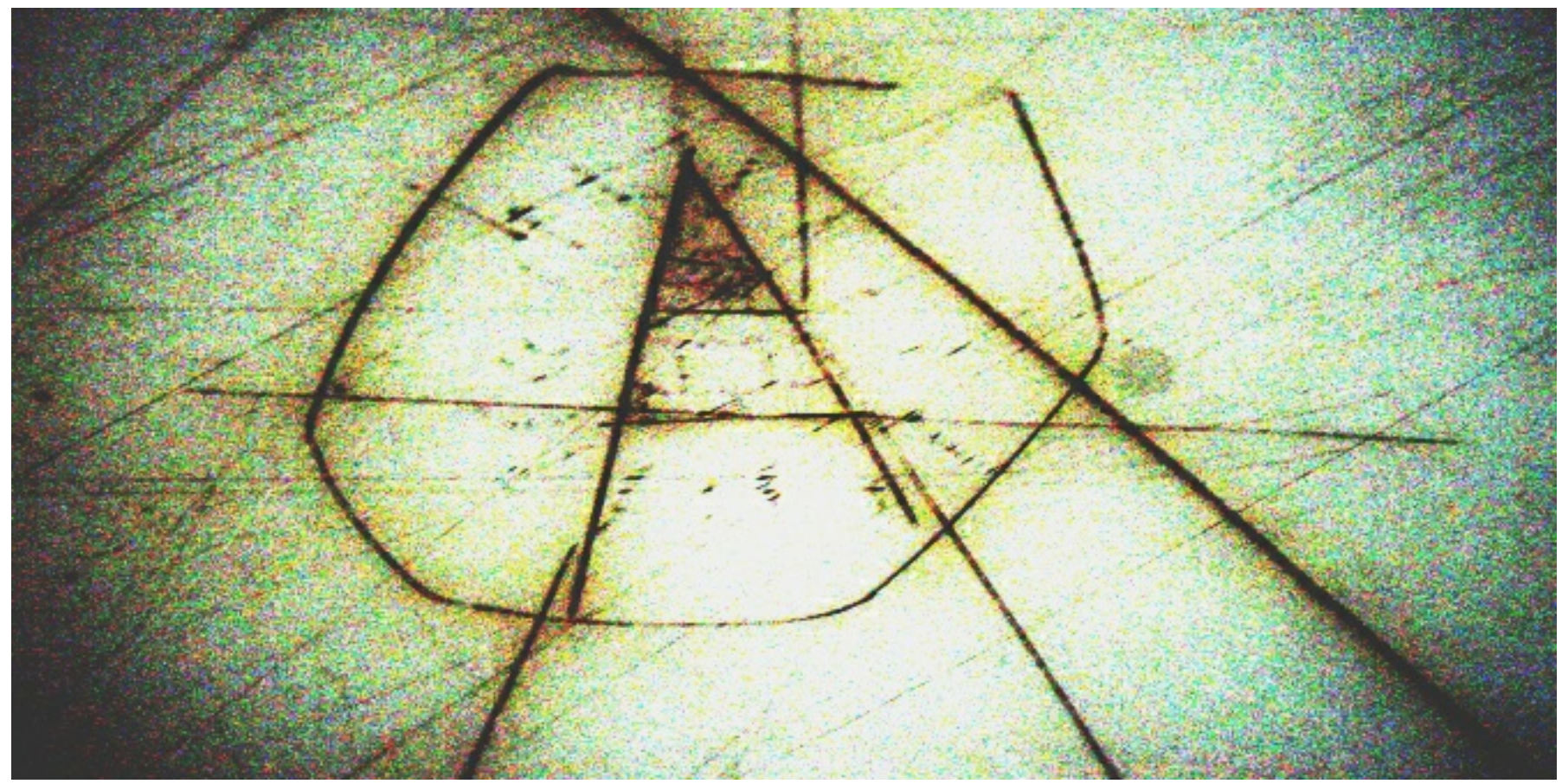

\section{Image Credit: (Quinn Dombrowski CC BY SA 2.0)}

After establishing a historical foundation of anarchist thought, Mac Laughlin moves into Kropotkin's early life including his upbringing as a Russian prince - as well as his formative years spent in the army. In describing Kropotkin's time in Siberia as a Russian army officer, Mac Laughlin compares the Russian frontier to the US one. He says: 'Each wave of westward expansion [in the United States], achieved through the conquest of nature and the annihilation of space, sent shock waves back east and fostered the growth of American democracy' (81). There is an obvious issue here of ignoring the government-sanctioned destruction of indigenous culture and life in the Americas at the hands of settler-colonists. The US idea of 'democracy' - which is not really democracy anyway, as was presented by a recent Princeton study - was certainly spread, but only for those that could afford it; during this time, it was overwhelmingly white, Christian men. Furthermore, there is no mention of Manifest Destiny, the doctrine that the American people were blessed and that the expansion westward was divinely justified and inevitable, leading to the genocidal tendency of settlers toward the indigenous population. When speaking of the Russian expansion, Mac Laughlin says: 'Far from nurturing the growth of civic society and democracy, frontier expansion in nineteenthcentury Russia was achieved at the expense of local communities and contributed to the consolidation of state authority' (81). This comparison between an American frontier that supposedly fostered democracy and a Russian one that restricted it is fallacious as one could make the argument that a similar situation was happening in the Americas as was occurring in Russia.

Other than this minor squabble, Mac Laughlin's historical discourse is interesting and comprehensive. Mac Laughlin does not shy away from Kropotkin's faults either, such as his misogynistic dismissal of women's role within the revolution (101-2). The author's refusal to contribute to the cult of personality that sometimes surrounds political theorists is appreciated.

However, the real jewel is in the second half of the book in which Mac Laughlin discusses scientific anarchism, an ontology of anarchist ethics and altruism as well as a treatise towards an anarchist political geography. Mac Laughlin contributes to the growing literature wishing to inject academic disciplines with anarchist principles, such as Simon Springer's The Anarchist Roots of Geography: Toward Spatial Emancipation, David Graeber's Fragments of an Anarchist Anthropology and Paul Feyerabend's seminal Against Method: Outline of an Anarchist Theory of Knowledge. According to Kropotkin, the foundation of these principles - the 'ontological basis of anarchist altruism' was 'derived from an innate moral sense of justice, rather than from any aristocratic or philanthropic desire to simply 
“do good" for those less fortunate than himself' (154).

These altruist ethics spilled over into Kropotkin's philosophy on education. 'Popular education, [Kropotkin] argued, could [...] empower the poor and the uneducated, thereby providing them with the tools to interpret and reconstruct the world about them in their image, rather than that of their rulers' (156). It could be argued that Kropotkin's educational philosophy lives on today with many of the alternative schooling movements, most notably the philosophy of unschooling.

Kropotkin - being a scientist and academic as well as a political revolutionary - became disillusioned with the academic field of geography. While he enjoyed conducting academic work, Mac Laughlin argues that he did not like how the field was becoming more pragmatic and technocratic; furthermore, many academic disciplines in this time were being incorporated into the service of the military establishment and colonial elites (202). In the past decade, we have seen the continued co-opting of the social sciences in order to serve the military-industrial complex in the form of the Human Terrain System programme in the United States.

Mac Laughlin - like Kropotkin before him - makes an argument for geography to become an 'emancipatory discipline' (217). More broadly, Mac Laughlin puts out a call-to-action for anarchist academics to continue critically re-evaluating early anarchist theorists like Proudhon, Jacques Élisée Reclus, Kropotkin and Mikhail Bakunin. He claims that we are living in a social, technological and political environment that is ripe for the proliferation of anarchist ideas. Mac Laughlin's latest book is an excellent contribution to this 'anarchist Renaissance' and should be read and referenced by all those who hope to heed the call to revolutionary praxis.

Taylor R. Genovese is currently a graduate student in sociocultural anthropology at Northern Arizona University. His academic interests include the anthropology of outer space, social movements, futures, social imaginaries, anarchism, decolonization and planetary/deep space analogues. You can find out more about him and his research at taylorgenovese.com. You can also follow him on Twitter @trgenovese.

Note: This review gives the views of the author, and not the position of the LSE Review of Books blog, or of the London School of Economics.

- Copyright 2013 LSE Review of Books 